\title{
Evaluation of TMJ articular eminence morphology and disc patterns in patients with disc displacement in MRI
}

\author{
Avaliação da morfologia da eminência e dos \\ padrões do disco articular em pacientes com \\ deslocamento de disco em IRM
}

Fabio Henrique Hirata ${ }^{(a)}$

Antônio Sérgio Guimarães ${ }^{(a)}$

Jefferson Xavier de Oliveira ${ }^{(b)}$

Carla Ruffeil Moreira ${ }^{(c)}$

Evangelo Tadeu Terra Ferreira ${ }^{(b)}$

Marcelo Gusmão Paraiso Cavalcanti ${ }^{(b)}$

(a) MScs, Department of Morphology, College of Medicine, Federal University of São Paulo.

(b) PhDs, Department of Radiology, School of Dentistry, University of São Paulo.

(c) MSc, Department of Stomatology, School of Dentistry of Bauru, University of São Paulo.

\footnotetext{
Corresponding author:

Marcelo Gusmão Paraiso Cavalcanti

Disciplina de Radiologia, Departamento de Estomatologia

Faculdade de Odontologia da Universidade de São Paulo (FOUSP)

Av. Lineu Prestes, 2227, Cidade Universitária

São Paulo - SP - Brazil

CEP: 05508-000

E-mail:mgpcaval@usp.br
}

Received for publication on Feb 07, 2006

Sent for alterations on Nov 29, 2006

Accepted for publication on Feb 11, 2007

\begin{abstract}
The aim of this study was to assess the shape of the temporomandibular joint (TMJ) articular eminence and the articular disc configuration and position in patients with disc displacement. TMJ magnetic resonance images (MRI) of 14 patients with bilateral disc displacement without unilateral reduction were analyzed. Articular eminence morphology was characterized as box, sigmoid, flattened, or deformed. Articular disc configuration was divided into biconcave, biplanar, biconvex, hemiconvex or folded, and its position, as "a" (superior), "b" (anterosuperior), "c" (anterior) or "d" (anteroinferior). The images were divided and the sides with disc displacement with reduction (DDWR) and without reduction (DDWOR) were compared. Regarding articular eminence shape, the sigmoid form presented the greatest incidence, followed by the box form, in the DDWR side, although this was not statistically significant. In the DDWOR side, the flattened shape was the most frequent $(\mathrm{p}=0.041)$. As to disc configuration, the biconcave shape was found in $79 \%$ of the DDWR cases $(\mathrm{p}=0.001)$ and the folded type predominated in $43 \%$ of the DDWOR cases ( $\mathrm{p}=0.008$ ). As to disc position, in the DDWR side, " $b$ " (anterosuperior position) was the most frequent $(\mathrm{p}=0.001)$, whereas in the DDWOR side, "d" (anteroinferior position) was the most often observed $(\mathrm{p}=0.001)$. The side of the patient with altered disc configuration and smaller shape of TMJ articular eminence seems to be more likely to develop non-reducing disc displacement as compared to the contralateral side.
\end{abstract}

Descriptors: Temporomandibular joint disorders; Temporomandibular joint disk; Temporomandibular joint dysfunction syndrome; Magnetic resonance imaging.

Resumo: Objetivou-se avaliar a morfologia da eminência e a configuração e a posição do disco da articulação temporomandibular (ATM) em pacientes com deslocamento de disco. Foram analisadas imagens por ressonância magnética (IRM) da ATM de 14 pacientes com deslocamento de disco bilateral, sem redução unilateral. A morfologia da eminência articular foi caracterizada como caixa, sigmóide, aplainada e deformada. A configuração do disco articular foi dividida em bicôncava, biplanar, biconvexa, hemiconvexa e dobrada e a sua posição em "a" (superior), "b" (ântero-superior), "c" (anterior) e "d" (ântero-inferior). As imagens foram divididas e comparadas entre o lado com deslocamento de disco com redução (DDCR) e o lado sem redução (DDSR). Quanto à forma da eminência articular, a forma sigmóide foi a mais incidente, seguida da caixa, no lado com DDCR, embora esta diferença não tenha sido estatisticamente significante. No lado com DDSR, a forma aplainada foi a mais freqüente $(\mathrm{p}=0,041)$. Na configuração do disco, a forma bicôncava foi observada em $79 \%$ dos casos de DDCR ( $p=0,001$ ) e a dobrada em $43 \%$ dos casos de DDSR ( $\mathrm{p}=0,008)$. Em relação à posição do disco, a posição "b" (ântero-superior) foi a mais freqüente no lado com DDCR ( $\mathrm{p}=0,001)$, enquanto que no lado com DDSR, foi a "d" (ântero-inferior) $(\mathrm{p}=0,001)$. O lado do paciente com alteração na configuração do disco e uma forma menor da eminência articular da ATM parece ter mais chance de desenvolver o deslocamento do disco sem redução quando comparado ao outro lado.

Descritores: Transtornos da articulação temporomandibular; Disco da articulação temporomandibular; Síndrome da disfunção da articulação temporomandibular; Imagem por ressonância magnética. 


\section{Introduction}

Magnetic resonance imaging (MRI) provides an excellent representation of soft tissues in anatomical and semi-functional relationships. The multisection images allow a tridimensional analysis of the temporomandibular joint (TMJ), providing the most complete assessment of the relationship of the mandibular head, articular disc, mandibular fossa and articular eminence. ${ }^{10}$ The TMJ is a bilateral articulation, connected to the mandible and interdependent, with its own movements in each side yet simultaneous, and could be considered as one sole joint. ${ }^{15}$ Several studies have assessed the TMJ as an individual or unilateral structure, , $3,12,18,20,22,23,24_{\text {not }}$ taking into account the contralateral side.

Internal disorders of the TMJ have been defined as an abnormal positional relationship between the disc and the condyle, articular eminence, and/or articular fossa. ${ }^{18}$ It has been argued that the articular eminence morphology may be a factor in the etiology of internal TMJ disorders. . $^{8,911-14,19-21,25}$ Some authors have suggested that greater articular eminence inclination would be a predisposing factor for internal disorders, ${ }^{9,20,21}$ even though other studies did not support these results. , $^{8,11,13,14,19}$ Articular eminence flattening can be a result of internal disorders. ${ }^{5,12}$ The association of articular disc position and configuration in the TMJ with internal derangements, $2,3,12,18,20,22,24$ as well as temporomandibular disorders, ${ }^{1,4-7,16,17,23}$ has also been reported by many authors.

The objective of this retrospective study was to assess the morphology of the articular eminence and articular disc on the side with disc displacement with reduction (DDWR) and on the side with disc displacement without reduction (DDWOR) in the same patient.

\section{Material and Methods}

The study protocol was submitted to and approved by the Research Ethics Committee, Federal University of São Paulo (CEP 1334/03). The investi-

Figure 1 - Classification of articular eminence shapes: $(\mathbf{A})$ box, $(\mathbf{B})$ sigmoid, (C) flattened, (D) deformed.
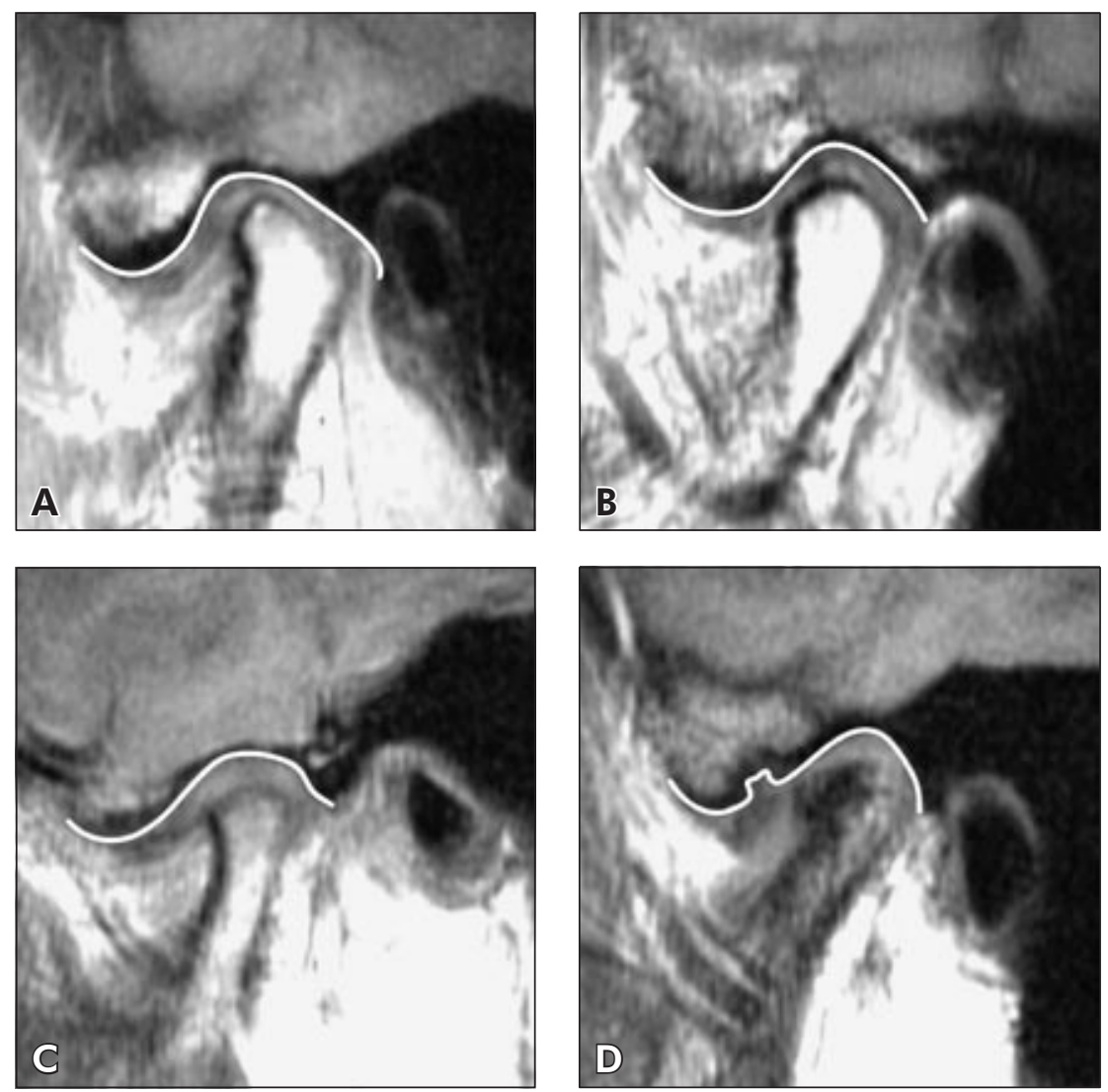
gation was based on a retrospective study of 14 selected patients (11 females, 3 males), with signs and/ or symptoms of temporomandibular disorders, who were submitted to TMJ MRI in a Philips Gyroscan ACS - II 1.5 Tesla (Philips Medical Systems, Best, Netherlands) in the closed-mouth, maximum opening and pseudodynamic positions, which presented unilateral DDWOR. The images were obtained in T1 (TR 500, TE 15) with 4-mm oblique-sagittal slices with no spacing.

Articular eminence morphology was classified into four types, according to the criteria set by $\mathrm{Ku}-$ rita et al..$^{13}$ (2000): box, sigmoid, flattened or deformed (Figure 1). In order to assess disc configuration, the criterion of Murakami et al. ${ }^{18}$ (1993) was applied, and the disc was characterized, according to its shape, as biconcave, biplanar, biconvex, hemiconvex or folded (Figure 2).

Disc position was classified following the criterion set by Murakami et al. ${ }^{18}$ (1993) (Figure 3). In the maximum opening position, the space was di- vided into two compartments - anterior and posterior - by a line passing through the point at which the mandible head was closest to the articular eminence surface. If the disc was anterior to this line, it was considered without reduction (WOR); if posterior, it was considered with reduction (WR). In closed-mouth position, the disc space was divided into four compartments: "a" was the superior position of the disc; "b", the anterosuperior position; "c", the anterior position; and "d", the anteroinferior position.

For statistical analysis, the sample was divided into DDWR and DDWOR. The exact Fisher test was used to evaluate differences in the distribution of shapes or positions. The level of significance was set at $5 \%$.

\section{Results}

The sample consisted of 28 joints with disc displacement, 14 DDWR and 14 DDWOR. The results of the classification of the articular eminence
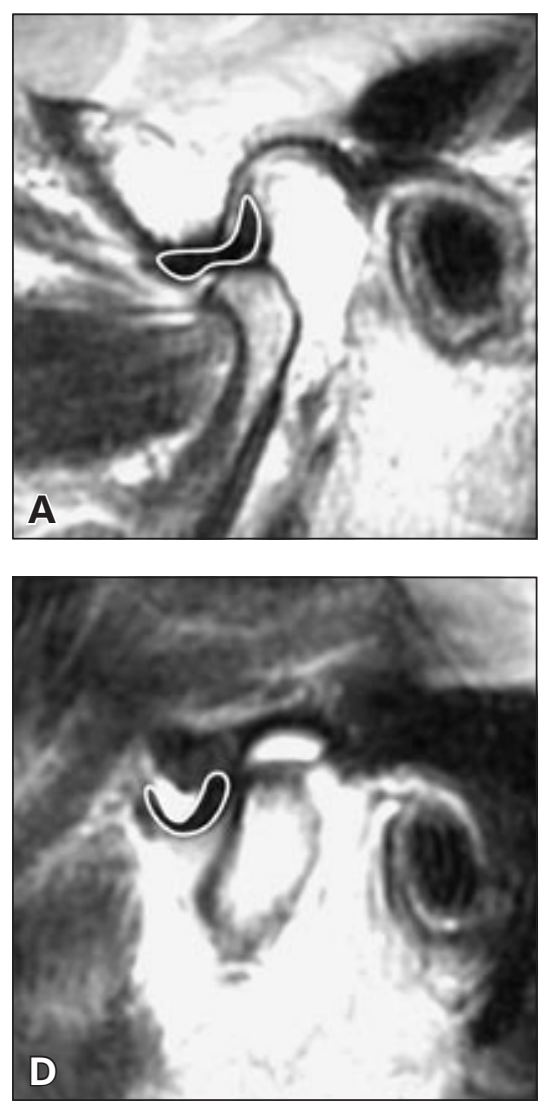
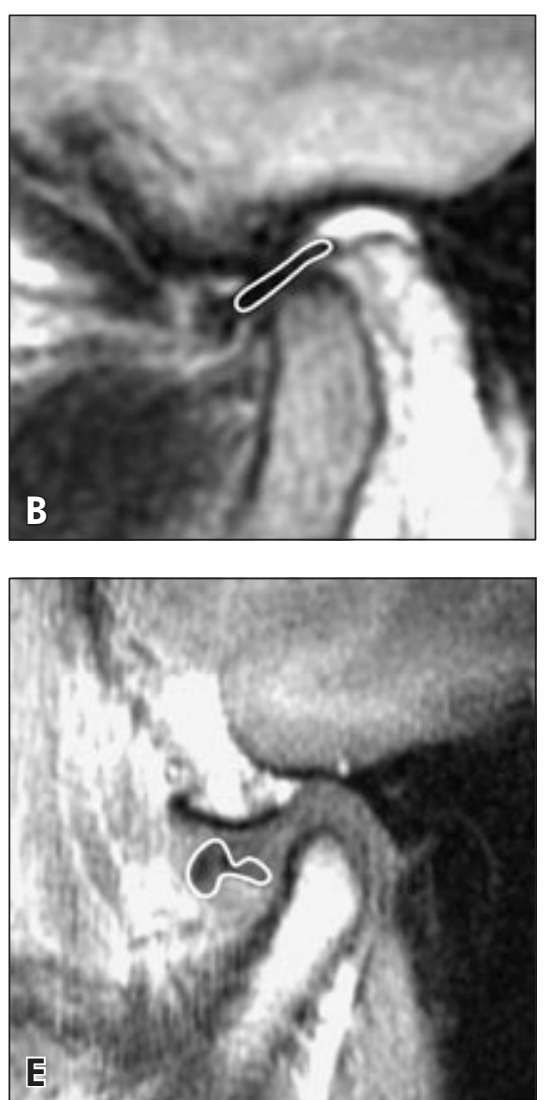

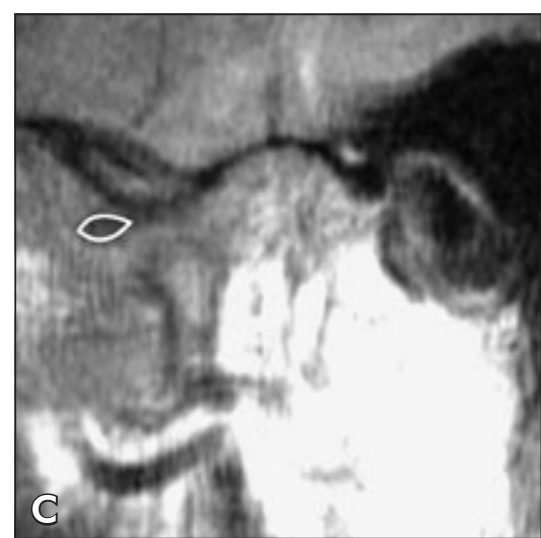

Figure 2 - Classification of disc configuration: (A) biconcave, (B) biplanar, (C) biconvex, (D) hemiconvex, (E) folded. 

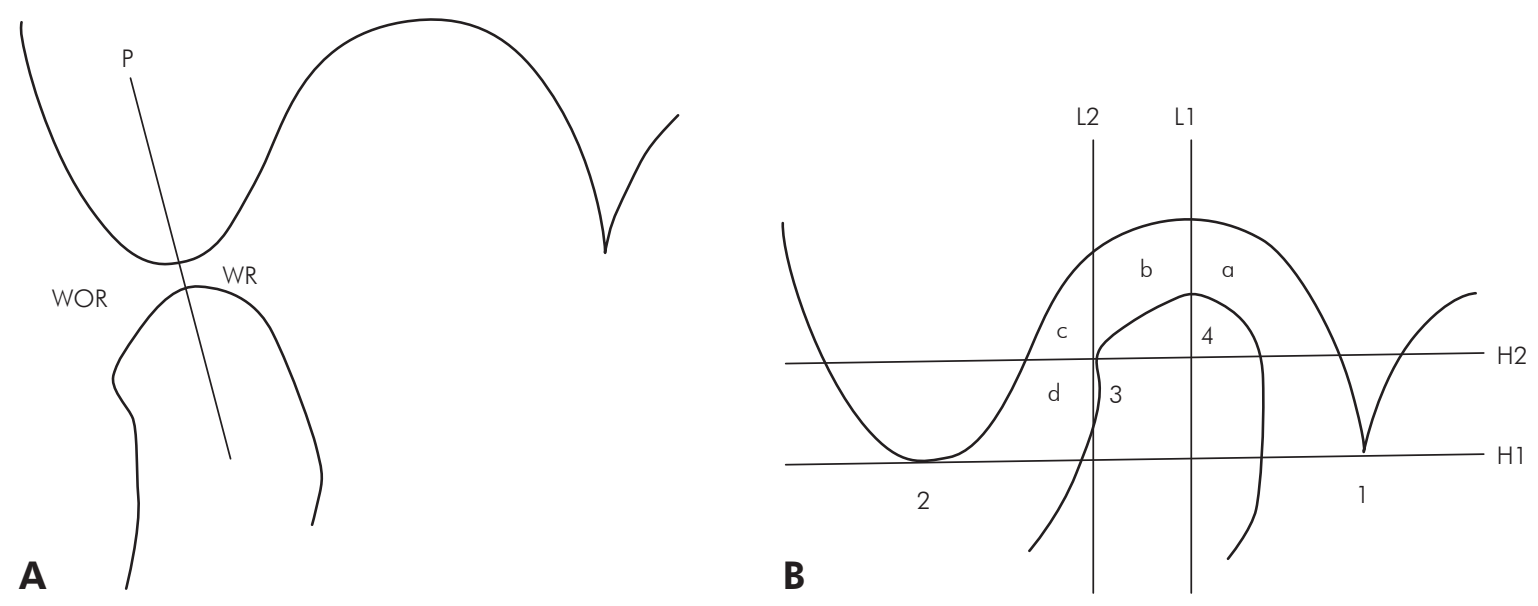

Figure 3 - Criteria for disc position. A: In open-mouth position, the disc space was divided in anterior (WOR - without reduction) and posterior (WR - with reduction) according to $\mathbf{P}$, a line passing through the point at which the condyle is closest to the articular eminence. B: In closed-mouth position, the disc position was classified according to whether the posterior band was in compartment $\mathbf{a}, \mathbf{b}, \mathbf{c}$ or $\mathbf{d}$. $\mathbf{H 1}$, tangent from the postglenoid process (1) to articular eminence $(\mathbf{2})$. $\mathbf{H} \mathbf{2}$, line parallel to $\mathbf{H} \mathbf{1}$ passing through the anterior edge (3) of the functional surface of the condyle. L1, line passing through the posterior edge (4) of the fuctional surface of the condyle. L2, line parallel to L1 passing through the anterior edge (3) of the condyle surface. [Modified from Murakami et al. ${ }^{18}$ (1993)].

Table 1 - Distribution of the articular eminence shapes on the sides with disc displacement with reduction (DDWR) and without reduction (DDWOR).

\begin{tabular}{l|c|c|c}
\hline \multirow{2}{*}{$\begin{array}{c}\text { Eminence } \\
\text { shapes }\end{array}$} & DDWR & DDWOR & \multirow{2}{*}{ P values } \\
\cline { 2 - 3 } Box & $\mathrm{N}(\%)$ & $\mathrm{N}(\%)$ & \\
\hline Sigmoid & $5(36)$ & $2(14)$ & $0.385 \mathrm{NS}$ \\
\hline Flattened & $7(50)$ & $5(36)$ & $0.478 \mathrm{NS}$ \\
\hline Deformed & $1(7)$ & $6(43)$ & $0.041^{*}$ \\
\hline
\end{tabular}

$\mathrm{N}=$ sample; $*$ Statistically significant; NS = not significant.

shape are shown in Table 1. The flattened shape was the most frequent on the side without reduction $(\mathrm{p}=0.041)$.

Table 2 presents the distribution of the articular eminence shapes in DDWR and DDWOR in the same patient. Sigmoid-flattened was the most prevalent shape $(29 \%)$, followed by box-sigmoid $(21 \%)$.

Table 3 reveals that, in DDWR, the biconcave configuration of the disc was found in $79 \%$. However, in DDWOR, only $7 \%$ presented the same con-
Table 2 - Assessment of the articular eminence on the sides with disc displacement with reduction (DDWR) and without reduction (DDWOR) in the same patient.

\begin{tabular}{l|l|c}
\hline \multicolumn{1}{c|}{ DDWR } & DDWOR & $\mathrm{N}(\%)$ \\
\hline Box & Box & $1(7)$ \\
\hline Box & Sigmoid & $3(21)$ \\
\hline Box & Flattened & $1(7)$ \\
\hline Sigmoid & Box & $1(7)$ \\
\hline Sigmoid & Sigmoid & $1(7)$ \\
\hline Sigmoid & Flattened & $4(29)$ \\
\hline Sigmoid & Deformed & $1(7)$ \\
\hline Flattened & Sigmoid & $1(7)$ \\
\hline Deformed & Flattened & $1(7)$ \\
\hline
\end{tabular}

$\mathrm{N}=$ sample.

figuration ( $\mathrm{p}=0.001)$, and the folded-type predominated with $43 \%$ ( $\mathrm{p}=0.008$ ).

The distribution of the posterior band position is presented in Table 4. In DDWR, " $b$ " - the anterosuperior position - was the most frequent $(\mathrm{p}=0.001)$, whereas in DDWOR, " $\mathrm{d}$ " - the anteroinferior position - was the most often observed $(\mathrm{p}=0.001)$. 
Table 3 - Distribution of disc configurations on the sides with disc displacement with reduction (DDWR) and without reduction (DDWOR).

\begin{tabular}{|c|c|c|c|}
\hline \multirow{2}{*}{$\begin{array}{c}\text { Disc } \\
\text { configurations }\end{array}$} & DDWR & DDWOR & \multirow{2}{*}{$P$ values } \\
\hline & N (\%) & N (\%) & \\
\hline Biconcave & 11 (79) & 1 (7) & $0.001^{*}$ \\
\hline Biplanar & $3(21)$ & 1 (7) & $0.596 \mathrm{NS}$ \\
\hline Biconvex & $0 \quad(0)$ & $3(21)$ & $0.222 \mathrm{NS}$ \\
\hline Hemiconvex & $0 \quad(0)$ & $3(21)$ & $0.222 \mathrm{NS}$ \\
\hline Folded & $0 \quad(0)$ & $6(43)$ & $0.008^{*}$ \\
\hline
\end{tabular}

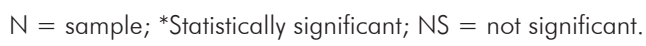

\section{Discussion}

Is there a real influence of eminence shape and/or disc characteristics on determining whether a displaced disc is reducible or nonreducible? The broad discussion about the predisposing factors for the development of internal TMJ disorders led to the development of diverse models to assess the association of anatomical structures with these disorders. It was important to divide these structures into groups in order to compare both sides and have a functional view of the TMJ, considering that most studies did not take that into account. ${ }^{1-25}$

In this study, the articular eminence shape was classified into four groups according to the criteria of Kurita et al. ${ }^{13}$ (2000). As in our results, those authors observed a trend towards a more sigmoid shape, followed by the box shape, in DDWR, although this was not statistically significant. In DDWOR, they found a significant difference in the prevalence of the flattened shape. We also found a statistically significant difference in the distribution of the flattened shape between DDWOR (43\%) and DDWR (7\%) (Table 1). Some studies have considered articular eminence flattening as a secondary result to internal derangements. ${ }^{12,13,21}$

The box shape represents a larger articular eminence or a deeper articular fossa than found in the sigmoid and flattened shapes. The sigmoid shape is more likely to have a larger articular eminence or a deeper articular fossa in the articular eminence than the flattened shape. The flattened shape is the shallowest.
Table 4 - Distribution of the posterior band position on the sides with disc displacement with reduction (DDWR) and without reduction (DDWOR).

\begin{tabular}{l|c|c|l}
\hline \multirow{2}{*}{ Posterior band positions } & DDWR & DDWOR & \multirow{2}{*}{ P values } \\
\cline { 2 - 3 } & $\mathrm{N}(\%)$ & $\mathrm{N}(\%)$ & \\
\hline $\mathrm{a}$ (superior position) & $2(14)$ & $0(0)$ & $0.481 \mathrm{NS}$ \\
\hline $\mathrm{b}$ (anterosuperior position) & $9(64)$ & $0(0)$ & $0.001^{*}$ \\
\hline $\mathrm{c}$ (anterior position) & $2(14)$ & $4(29)$ & $0.648 \mathrm{NS}$ \\
\hline $\mathrm{d}$ (anteroinferior position) & $1(7)$ & $10(71)$ & $0.001^{*}$ \\
\hline
\end{tabular}

$\mathrm{N}=$ sample; *Statistically significant; NS = not significant.

While assessing the influence of the TMJ on DDWR and DDWOR in the same patient, it was observed that larger eminences were more predominant on the side with reduction than on the non-reducing discs (box-sigmoid, box-flattened, sigmoid-flattened), accounting for $57 \%$ of the cases. Moreover, $14 \%$ presented equal shapes (box-box and sigmoidsigmoid); $14 \%$ had shallower eminences on the side with reduction than on the side without reduction (sigmoid-box and flattened-sigmoid); 7\% presented the deformed shape on the side with reduction, and $7 \%$, on the side without reduction (Table 2).

The TMJ structures are preserved by disc interposition between the articular eminence and mandible head, as the disc is one of the elements responsible for absorbing the resulting articular movement forces. When any factor is in disharmony with this movement, the first to be remodeled would be the articular disc. If the disc no longer took part in this movement, the other structures would absorb this movement force, resulting in greater remodeling.

For disc configuration and position, we followed the criteria of Murakami et al. ${ }^{18}$ (1993). Regarding disc configuration, those authors found the biconcave configuration as the most common type in DDWR. In contrast, the biconvex and folded configurations were more frequent in DDWOR. We found a statistically significant difference in the distribution of the biconcave type between DDWR (79\%) and DDWOR (7\%). The folded type was statistically more prevalent in DDWOR (43\%) than in DDWR 
Figure 4 - Patient with same eminence shapes (box-box): $\mathbf{A}$ (reduced eminence on the right side) and $\mathbf{B}$ (eminence on the left side without reduction). Note that $\mathbf{B}$, however, is less inclinated than $\mathbf{A}$.
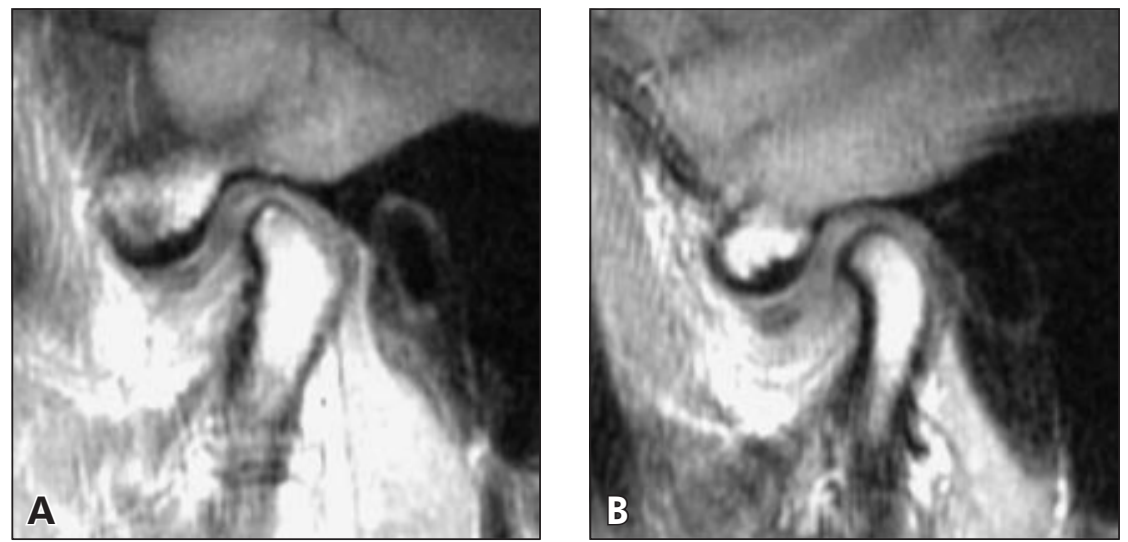

$(0 \%)$, followed by the biconvex and hemiconvex configurations (Table 3).

While assessing disc position, Murakami et al. ${ }^{18}$ (1993) found a 13\% rate of the "d" (anteroinferior) position in DDWR. In our study, we found this rate to be only $7 \%$, which was significantly different from the rate found in DDWOR (71\%). In contrast, in the side with reduction, the " $b$ " position (anterosuperior) was more predominant (64\%) (Table 4). We agree with Sato et al. ${ }^{20}$ (1999), who examined the disc position and its configuration changes. They demonstrated that, in cases of disc displacement, mandible head mobility increased with time, although its configuration did not change; consequently, there would be a more anterior displacement according to its larger deformity. In our study, the more anterior position of the posterior band was associated with greater alteration of disc configuration, when compared with a more superior position of the mandible head. We suggest that the capacity to reduce is more directly related to alterations in disc shape.

This work has some limitations considering that it was necessary to use a visual model to classify the TMJ structures. However, no other model was able to numerically express the several variables that articular eminences and articular discs may present. No significant differences were found in studies, using linear and angular measures, ${ }^{8,19}$ aimed to find a prevalence of anatomical forms by comparing asymptomatic groups and symptomatic volunteers. If we assess numerically an articular eminence with a box shape, we could find similar shapes in the same sample, but with different numeric values. A consensus has not been reached since it is difficult to establish a numerical model to assess the TMJ structures. Murakami et al. ${ }^{18}$ (1993) suggested using landmarks in the TMJ and not measuring them numerically. If we did so, in cases in which the anatomical structures had larger shapes, we would have false-positive results. If we had used models with linear or angular measures, our results could not have been significant. The numerical measures would have the objective of establishing patterns to classify TMJ but it would be impossible to exactly measure the sides in which similar and deformed shapes were found (Figure 4).

\section{Conclusion}

We concluded that alterations in morphology of the articular eminence and articular disc may influence the occurrence of non-reducing disc displacement on the side the alterations occur. Nevertheless, we feel that other factors should be investigated, such as the influence of deviation in the opening and closing movements, rotation and translation movements of each TMJ, unilateral mastication, unilateral pain, and unilateral articular sound.

\section{Acknowledgements}

We wish to thank CAPES (Moreira CR) from Brasília (DF, Brazil) for providing a scholarship; and Professor José Leopoldo Ferreira Antunes for advising on the statistical analysis. 


\section{References}

1. Bertram S, Rudisch A, Innerhofer K, Pumpel E, Grubwieser G, Emshoff R. Diagnosing TMJ internal derangement and osteoarthritis with magnetic resonance imaging. J Am Dent Assoc. 2001;132(6):753-61.

2. Cholitgul W, Nishiyama H, Sasai T, Uchiyama Y, Fuchihata $\mathrm{H}$, Rohlin $\mathrm{M}$. Clinical and magnetic resonance imaging findings in temporomandibular joint disc displacement. Dentomaxillofac Radiol. 1997;26(3):183-8.

3. de Leeuw R, Boering G, Stegenga B, de Bont LG. TMJ articular disc position and configuration 30 years after initial diagnosis of internal derangement. J Oral Maxillofac Surg. 1995;53(3):234-41.

4. Emshoff R, Brandlmaier I, Bertram S, Rudisch A. Comparing methods for diagnosing temporomandibular joint disk displacement without reduction. J Am Dent Assoc. 2002;133(4):442-51.

5. Emshoff R, Brandlmaier I, Bertram S, Rudisch A. Risk factors for temporomandibular joint pain in patients with disc displacement without reduction - a magnetic resonance imaging study. J Oral Rehabil. 2003;30(5):537-43.

6. Emshoff R, Innerhofer K, Rudisch A, Bertram S. Clinical versus magnetic resonance imaging findings with internal derangement of the temporomandibular joint: an evaluation of anterior disc displacement without reduction. J Oral Maxillofac Surg. 2002;60(1):36-41.

7. Emshoff R, Rudisch A, Innerhofer K, Brandlmaier I, Moschen I, Bertram S. Magnetic resonance imaging findings of internal derangement in temporomandibular joints without a clinical diagnosis of temporomandibular disorder. J Oral Rehabil. 2002;29(6):516-22.

8. Galante G, Paesani D, Tallents RH, Hatala MA, Katzberg RW, Murphy W. Angle of the articular eminence in patients with temporomandibular joint dysfunction and asymptomatic volunteers. Oral Surg Oral Med Oral Pathol Oral Radiol Endod. 1995;80(2):242-9.

9. Hall MB, Gibbs CC, Sclar AG. Association between the prominence of the articular eminence and displaced TMJ disks. Cranio. 1985;3(3):237-9.

10. Hasso AN, Christiansen EL, Alder ME. The Temporomandibular Joint. Radiol Clin North Am. 1989;27(2):301-14.

11. Kinniburgh RD, Major PW, Nebbe B, West K, Glover KE. Osseous morphology and spatial relationships of the temporomandibular joint: comparisons of normal and anterior disc positions. Angle Orthod. 2000;70(1):70-80.

12. Kurita H, Ohtsuka A, Kobayashi H, Kurashina K. Flattening of the articular eminence correlates with progressive internal derangement of the temporomandibular joint. Dentomaxillofac Radiol. 2000;29(5):277-9.

13. Kurita H, Ohtsuka A, Kobayashi H, Kurashina K. Is the morphology of the articular eminence of the temporomandibular joint a predisposing factor for disc displacement? Dentomaxillofac Radiol. 2000;29(3):159-62.
14. Kurita H, Ohtsuka A, Kobayashi H, Kurashina K. The relationship between the degree of disk displacement and ability to perform disk reduction. Oral Surg Oral Med Oral Pathol Oral Radiol Endod. 2000;90(1):16-20.

15. Madeira MC. Articulação temporomandibular. In: Madeira MC. Anatomia da face: bases anátomo-funcionais para a prática odontológica. São Paulo: Sarvier; 1995.

16. Milano V, Desiate A, Bellino R, Garofalo T. Magnetic resonance imaging of temporomandibular disorders: classification, prevalence and interpretation of disc displacement and deformation. Dentomaxillofac Radiol. 2000;29(6):352-61.

17. Minakuchi H, Kuboki T, Matsuka Y, Maekawa K, Yatani $\mathrm{H}$, Yamashita A. Randomized controlled evaluation of nonsurgical treatments for temporomandibular joint anterior disk displacement without reduction. J Dent Res. 2001;80(3):9248 .

18. Murakami S, Takahashi A, Nishiyama H, Fujishita M, Fuchihata H. Magnetic resonance evaluation of the temporomandibular joint disc position and configuration. Dentomaxillofac Radiol. 1993;22(4):205-7.

19. Ren YF, Isberg A, Westesson PL. Steepness of the articular eminence in the temporomandibular joint. Tomographic comparison between asymptomatic volunteers with normal disk position and patients with disk displacement. Oral Surg Oral Med Oral Pathol Oral Radiol Endod. 1995;80(3):258-66.

20. Sato S, Sakamoto M, Kawamura H, Motegi K. Long-term changes in clinical signs and symptoms and disc position and morphology in patients with nonreducing disc displacement in the temporomandibular joint. J Oral Maxillofac Surg. 1999;57(1):23-9.

21. Sulun T, Cemgil T, Duc JM, Rammelsberg P, Jager L, Gernet W. Morphology of the mandibular fossa and inclination of the articular eminence in patients with internal derangement and in symptom-free volunteers. Oral Surg Oral Med Oral Pathol Oral Radiol Endod. 2001;92(1):98-107.

22. Taskaya-Yilmaz N, Ogutcen-Toller M. Magnetic resonance imaging evaluation of temporomandibular joint disc deformities in relation to type of disc displacement. J Oral Maxillofac Surg. 2001;59(8):860-5.

23. Taskaya-Yylmaz N, Ogutcen-Toller M. Clinical correlation of MRI findings of internal derangements of the temporomandibular joints. Br J Oral Maxillofac Surg. 2002;40(4):31721.

24. Toyama M, Kurita K, Westesson PL, Sakuma S, Ariji E, Rivera R. Decreased disk-eminence ratio is associated with advanced stages of temporomandibular joint internal derangement. Dentomaxillofac Radiol. 1999;28(5):301-4.

25. Yatani H, Sonoyama W, Kuboki T, Matsuka Y, Orsini MG, Yamashita A. The validity of clinical examination for diagnosing anterior disk displacement with reduction. Oral Surg Oral Med Oral Pathol Oral Radiol Endod. 1998;85(6):647-53. 